\title{
Scepticism about the argument from divine hiddenness
}

\author{
JUSTIN P. MCBRAYER \\ Department of Philosophy, Fort Lewis College, Durango, CO 81301, USA \\ e-mail: mcbrayer_j@fortlewis.edu
}

\section{PHILIP SWENSON}

University of California-Riverside, HMNSS Building, Room 1604, 900 University Avenue, Riverside, CA 92521, USA

e-mail:pswen001@student.ucr.edu

\begin{abstract}
Some philosophers have argued that the paucity of evidence for theism - along with basic assumptions about God's nature - is ipso facto evidence for atheism. The resulting argument has come to be known as the argument from divine hiddenness. Theists have challenged both the major and minor premises of the argument by offering defences. However, all of the major, contemporary defences are failures. What unites these failures is instructive: each is implausible given other commitments shared by everyone in the debate or by theists in particular. Only challenges which are plausible given both common sense and other theistic commitments will undermine the argument from divine hiddenness. Given that such defences universally fail, the best hope for a successful challenge to the argument comes from more general sceptical responses. This sort of response is briefly sketched and defended against four independent objections.
\end{abstract}

Some philosophers of religion have argued that the paucity of evidence for theism - along with basic assumptions about God's nature - is ipso facto evidence for atheism. The resulting argument has come to be known as the argument from divine hiddenness. Theists have challenged both the major and minor premises of the argument from divine hiddenness. But prominent, recent responses of each sort fail. What unites these failures is instructive: each is implausible given other commitments shared by everyone in the debate or by theists in particular. If theists hope to mount a serious challenge to the argument, they must ensure that the implications of their challenge are plausible given both common sense and other theistic commitments. We suggest that sceptical responses of the sort offered by sceptical theists are the best bet to undermining the argument from divine hiddenness. 


\section{The argument from divine hiddenness}

The argument from divine hiddenness has been defended most carefully by J. L. Schellenberg $(1993,2005 a, 2005 b, 2007) .{ }^{1}$ The basic line of argument is as follows:

(1) If there is a God, he is perfectly loving.

(2) If a perfectly loving God exists, reasonable non-belief does not occur.

(3) Reasonable non-belief occurs.

(4) No perfectly loving God exists. [from 2, 3]

(5) There is no God. [from 1, 4] ${ }^{2}$

While a more sophisticated version of the argument has recently been presented by Professor Schellenberg, this basic form of the argument is sufficient for present purposes. $^{3}$

What is to be said about the argument? Theists are committed to premise (1) because God is a perfect being. Given traditional theism, premise (1) is a conceptual truth, and thus denying (1) is a way out of the argument only at the cost of giving up traditional theism. For this reason, challenges to the argument have focused on either premise (2) or (3). The first section of this article recounts defences aimed at undermining premise (2), and the second section recounts arguments that purport to show that premise (3) is false. The final section of the article offers closing thoughts both on the (lack of) success of contemporary responses and on the soundness of the argument from divine hiddenness given more general sceptical considerations.

\section{Challenges to premise (2)}

Challenges to premise (2) almost always take the form of a defence. This section explains the difference between a defence and a theodicy, sketches the desiderata for a successful defence, and then shows how major defences in the recent literature come up short.

The terms 'theodicy' and 'defence' are not always used systematically. For example, the standards for a successful defence to the logical argument from evil are much, much lower than the standards of success for a successful defence to the evidential argument from evil. For this reason, it's worth being clear about what each of these concepts designates as applied to the argument from divine hiddenness.

As presented here, the argument from divine hiddenness is an evidential argument that purports to show that divine hiddenness is evidence against the existence of God even though it is logically consistent with the existence of God. ${ }^{4}$ According to the argument from divine hiddenness, reasonable non-belief is an indicator of the non-existence of God. In response to this, a theodicy for 
divine hiddenness is any set of statements that entails that premise (2) is false conjoined with assertion that each member of the set of claims is true. Similarly, a defence is any set of claims that entails that premise (2) is false conjoined with the assertion that each member of the set of claims is true for all we know. Peter van Inwagen's (2006) discussion of the difference is particularly lucid:

Typically, apologists dealing with the argument from evil present what are called 'defenses'. A defense is not necessarily different from a theodicy in content. Indeed, a defense and a theodicy may well be verbally identical. Each is, formally speaking, a story according to which both God and evil exist. The difference between a defense and a theodicy lies not in their content but in their purpose. A theodicy is a story that is told as the real truth of the matter; a defense is a story that, according to the teller, may or may not be true, but which, the teller maintains, has some desirable feature that does not entail truth ... (7)

As applied to the argument from divine hiddenness, a theodicy purports to present God's actual reasons for allowing reasonable non-belief, whereas a defence purports to present God's possible reasons for allowing reasonable nonbelief.

Two examples should suffice to make the distinction clear. When a defence attorney presents an alternative crime theory that the DA cannot rule out, she has presented a defence. She need not claim that her theory is, in fact, correct. She only needs to show that it would prove her client's innocence and that the DA cannot rule it out. Similarly, intelligent design theorists confront evolutionary biologists with particularly tricky instances of apparent design in nature. To defend their views successfully, the evolutionary biologists need not come up with a theory for how the apparent design actually happened. It's enough for them to describe a way that it might have happened naturally that we are in no position to rule out.

So a successful defence of the argument from divine hiddenness must meet two desiderata:

- It must be a description of a possible world in which God exists and at least some reasonable non-belief occurs.

- It must be a description that we are in no position to rule out.

This last condition is crucial. Just as it is insufficient for the defence attorney to point out that the evidence is logically consistent with her client's innocence, so, too, it is insufficient for the defender to point out that reasonable non-belief in God is logically consistent with the existence of God. Instead, the defender faces the higher burden of making the defence plausible in light of other commitments that we have. However, many contemporary responses to premise (2) fail to do so. What follows is a canvass of some recent defences from the literature. 


\section{Coercion defence}

One criticism of premise (2) is the suggestion that it might be morally wrong for God to reveal himself to us. The most prominent defence of this sort claims that belief in God might be coercive in some way, thus giving God a moral reason to prevent such belief. Michael Murray $(1993,2002)$ has suggested that orthodox Christians, at least, have the resources available to mount such challenge to premise (2) because 'making us powerfully aware of the truth of God's existence would suffice to coerce (at least many of) us into behaving in accordance with God's moral commands' (Murray (2002), 63). ${ }^{5}$ Murray points out that, in the Christian tradition, God's existence presents a serious threat to human beings: the threat of punishment both in this life and for eternity. Murray suggests that these threats coerce behaviour in a way which is inconsistent with the occurrence of morally significant free choices. ${ }^{6}$ Thus God must limit the 'epistemic imminence' of these threats by preventing individuals from gaining knowledge of his existence. The argument is straightforward:

\footnotetext{
one cannot act freely when one is in the condition of compulsion by another in the context of a threat ... [furthermore] if God does not remain 'hidden' to a certain extent, at least some of the free creatures He creates would be in the condition of being compelled in the context of a threat, and, as a result, such creatures could not exercise their freedom in this robust, morally significant manner. (Murray (1993), 29)
}

In response to the objection, notice first that the objector cannot be insisting that God doesn't provide the necessary evidence because it would coerce people into believing that God exists. Coercion is a moral notion. Belief is a cognitive one. To coerce someone is to get them to do something - to act in a certain way (or refrain from acting in a certain way). But believing is not an action. So, one cannot coerce belief. Instead, the objector must be insisting that evidence of God's existence would cause belief in his existence and that such belief would then somehow serve to coerce (or be the means of coercion of) the believer.

But it's clear that mere belief in the existence of someone is not ever sufficient to coerce. One must believe other things about the person and world before coercion could occur. Merely believing that there is a man in front of you is not sufficient to coerce you in any way. However, finding out that the man is holding a gun, that the gun is pointing at you, that the man is demanding your money, etc. might prove to be coercive. In the present case, mere belief in the existence of God would not be coercive unless one also believed the following kinds of things: (i) that God is perfectly just, (ii) that justice demands that one receive eternal punishment, (iii) that God ensures that people receive their just punishments, etc. And there seems no plausible reason why God couldn't provide us with belief in his existence while depriving us of evidence for other propositions that - when combined with the belief in his existence - might prove to be coercive. ${ }^{7}$ 
However, the coercion defence fails for a second reason as well. Recall that a successful defence has two desiderata - the second being that it must be consistent with other things that theists believe. The problem is that insisting that knowledge of God's existence poses such a severe threat creates significant problems for theists. To see this, suppose Murray is right that a high degree of confidence in the existence of God removes a person's ability to make morally significant free choices. This presents a problem for theists who claim to have such belief that God exists. For it seems that their knowledge of God's existence would then remove their capacity for making morally significant free choices. So the theist is left with three options:

(a) Accept that neither they nor anyone else who confidently believes that God exists makes morally significant free choices. ${ }^{8}$ or

(b) Deny they have confident belief that God exists. or

(c) Reject the coercion defence.

Neither (a) nor (b) will be palatable options for many theists. (a) is contrary to common sense (as well as conflicting with the views of many theists) and (b) is clearly in tension with the actual commitments of theists. Thus, the coercion defence fails the second criterion of a successful defence.

Perhaps anticipating this problem, Murray introduces the notion of the wantonness of the threatened. Wantonness is the "characteristic of the individual threatened to disregard personal well-being in the face of threats to his freedom' (Murray (1993), 31). To be wanton is to not be all that concerned about one's personal safety and thus not all that concerned about harm. Those with a high degree of wantonness are less vulnerable to threats and thus less likely to be coerced by threats. It could then be maintained that there are some with a high enough degree of wantonness that they would be able to perform morally significant free actions despite awareness of the threat posed by God's existence. And it is only these highly wanton people who are allowed by God to gain knowledge if his existence. ${ }^{9}$

This account, if correct, would provide a defence which would undermine premise (2). However, anyone wishing to endorse this account as a solution to the problem of divine hiddenness would be committed to the (implausible) claim that theists don't care as much about their personal well-being as do nontheists. More carefully, this response requires the truth of the following empirical claim:

All of those with knowledge of God's existence have a sufficiently high degree of wantonness to make morally significant free choices even when aware of the threat posed by the existence of God, and none of those who reasonably fail to believe that God exists have this degree of wantonness. 
Murray himself seems to agree that he is committed to such a claim (see Murray (2002), 77). However, this empirical claim is false. There is ample inductive evidence for the claim that there is no essential difference between theists and nontheists when it comes to their willingness to risk harm. And since we know this, we have conclusive reason to reject the coercion defence of divine hiddenness - the overall story is implausible since it relies on a false empirical claim. We do not have to wonder whether or not the story told by Murray is true - we know that it's false. Thus his story fails as a defence.

\section{Goods defence}

A second response insists not that God might be acting wrongly by revealing himself but that there might be a particular good (or set of goods) whose actualization requires the hiddenness of God. ${ }^{10}$ This is a common response to the argument (Hick (1971), McKim (1990) and (2001), Morris (1992), Keller (1995), Pascal (1995), Swinburne (2004) ), and all of them shall be considered together.

Recall again what would make the defence successful: it has to finger a particular good and argue that - for all we know - this good is unattainable without divine hiddenness. What goods might be at issue? Blaise Pascal (1995) suggests that it is simply a matter of respecting the wills/desires of human individuals:

Wishing to appear openly to those who seek him whole-heartedly, and to remain hidden from those who single-mindedly avoid him, God qualified the way he might be known so that he gave visible signs to those who seek him, and none to those who do not. There is enough light for those whose only desire is to see, and enough darkness for those of the opposite disposition. (81)

Another suggestion is that the good of having a relationship with God requires that God be hidden. For example, Hick (1971) suggests that 'for the sake of creating a personal relationship of love and trust with his human creatures God does not force an awareness of himself upon them' (105). Morris (1992) writes that 'it may be that the act of seeking reinforces, entrenches, and develops both humility and the love for truth' (103). Finally, like Murray, Swinburne (2004) suggests that:

\footnotetext{
a deep conviction of the existence of God inhibits someone's ability to choose freely between good and evil. It makes it too easy to choose the good for anyone who has either a strong desired to be liked by good persons ... or a strong desire for his own future well-being combined with a strong belief that it is quite likely that a God would not provide a good afterlife for bad people. $(268)^{11}$
}

The problem with all of these responses is parallel to the problem for the coercion response: by any theist's own admission, these goods are routinely realized in the lives of professed believers who have a forceful awareness of the existence of God. ${ }^{12}$ For example, theists embrace stories like that of scriptural patriarchs who supposedly walked with God and had conversations with him and 
who nevertheless acted wickedly at times and were deserving of punishment. Or consider the Apostle Paul who was literally struck blind in a powerful experience with God and who nonetheless apparently carried on a successful personal relationship with God, developed both humility and the love of truth, wrestled with moral problems, etc. There is no shortage of contemporary theists who admit that God's existence is perfectly obvious to them despite the fact that they profess a desire to be loved by God, to be engaged in what they describe as a healthy personal relationship with God, etc.; and yet nonetheless these same theists suffer from moral shortcomings, temptation, etc.

In light of examples such as these, theists and non-theists alike should agree that the fact that such goods are realized in the lives of believers provides a pro tanto case for the claim that divine hiddenness is not necessary for the procurement of such goods. Again, the defender could insist that actual non-believers are simply different from actual believers in the sense that hiddenness is necessary to achieve certain goods in their lives but not in the lives of the believers, but given our inductive evidence about the similarity between believers and nonbelievers - this empirical claim is extremely suspect. So once again, the goods defence fails the second criterion of a successful defence.

\section{Improper response defence}

A third and more promising line of argument for rejecting premise (2) is similar to the aforementioned defences with an important twist: not only is there a good that might require God's hiddenness, there might be an evil that can only be prevented by his hiddenness (Howard-Snyder (1996), Thune (2006), Van Inwagen (2006) ). Morris (1992) puts the point plainly: 'Perfect clarity, the free gift of unambiguous knowledge in matters of religion might for many people be dangerous ... and thus no gift at all' (98). Spelled out more carefully, the objection goes something like this:

\footnotetext{
God wants all persons to be in a certain type of relationship with him, and believing in God is a necessary condition for being in that relationship. However, belief in God is not sufficient for being in that type of relationship. Those who believe must take the further step of freely entering into the relationship. Now there are some people who (even if they did believe in God) would not enter into the desired relationship, in fact, their believing that God exists might make the situation worse because they would respond badly if they acquired this belief. Thus, God does not have a reason to ensure that these people learn that he exists, and he may in fact have a reason to refrain from informing them of his existence.
}

Call this the improper response objection. Unlike the previous defences, this defence lacks the implausible implication. However, the success of such a defence is still limited in an important respect. Since Schellenberg $(1993,1996)$ has presented several replies to this line of reasoning, it is important to consider his replies to see why they fail before proceeding to our analysis of the defence. 
First, Schellenberg (1996) simply denies that there are such individuals: '[if belief in God can] ... occur through religious experience, through a direct encounter with an omnipotent love capable of softening even the most selfcentered or embittered soul, then it seems that this class of individuals [who would be likely to respond badly] must be empty' (460). This is a very strong claim. If we suppose (as is plausible) that acting freely is incompatible with deterministic divine manipulation, then there may well be no way for God to guarantee that everyone will respond positively. So it is clearly possible that some will respond negatively to an encounter with God, and in fact it seems unlikely that every single person would respond positively. As Van Inwagen (2006) suggests, those who are extremely morally corrupt appear to be particularly good candidates to respond badly were they to gain knowledge of God's existence.

Second, Schellenberg suggests that even if someone were initially to respond badly to belief in God, God could continue attempting to change the person over time. While this is no doubt true, it is hard to see precisely how it alleviates the concern raised by the improper response objection. Even if God could continue trying to change a person who has responded badly to belief in him, it does not follow that he thereby lacks a good reason to avoid giving the person the opportunity to respond badly in the first place. And that is exactly what the improper response defence suggests is the case.

Third, Schellenberg argues that even if one is inclined to respond badly to evidence of God's existence, God still has a moral obligation to provide such evidence insofar as it is a necessary condition for a free choice of human destiny ( (1993), 151) ${ }^{13}$ The idea is that significant freedom requires a range of options, and so God would ensure that every potential believer has the option of choosing him despite a natural inclination to be a bad responder. In other words, it's worth the risk of generating a bad response in order to secure the necessary conditions for significant free choice. The problem with this response, as we see it, is that it does not take seriously the role of omniscience in divine deliberations. One could only deliberate in the way suggested by Schellenberg if one were ignorant about how the inclination to be a bad responder would turn out. However, if we accept the standard theistic claims about the extent of God's knowledge, then, for all we know, there are some people whom God knows would not respond positively to him no matter what. In that case, there would be no reason for him to 'take the risk' of generating a bad response by providing such people with evidence of his existence.

Thus none of Schellenberg's criticisms provides sufficient grounds for dismissing the improper response objection. On its face, the defence appears to provide good reason to reject premise (2). Recall the premise at issue:

(2) If a perfectly loving God exists, reasonable non-belief does not occur. 
Since it is plausible to accept that there is at least one person who would respond very badly to belief in God, it is plausible to hold that (2) is false. Perhaps, then, the improper response objection shows why Schellenberg's formulation of the argument from divine hiddenness is unsound.

However, despite this initial plausibility, the improper response defence does not offer a complete solution to the problem of divine hiddenness. The argument with which we began can simply be reformulated as an argument for atheism in a way that avoids the worry levied by the improper response objection. This is because it is implausible to hold that every single actual person who reasonably fails to believe that God exists would respond badly if they learned that God exists (let's call such a person a bad responder). ${ }^{14}$ In other words, in favour of the improper response objection, it seems that at least one person would be a bad responder. However, in favour of the argument from divine hiddenness, it seems implausible that every actual reasonable non-believer is a bad responder.

There are many individuals who (a) reasonably refrain from believing that God exits and (b) apparently would respond positively were they to learn that God does exist. Consider the agnostic who earnestly desires a relationship with God and has done her level best to try to find out if God exists, even praying that God (if he exists) will reveal himself to her. Or consider the person who seeks moral and spiritual truth but is from a society in which western theism is not taken to be a legitimate option. There are numerous reasonable non-believers who appear as though they would respond well to evidence for the existence of God. Thus it is implausible to hold that none of these apparently good responders are actually all bad responders. This offers a way of re-crafting the argument from divine hiddenness to avoid the improper response objection:

(1) If there is a God, he is perfectly loving.

(2') If a perfectly loving God exists, no good responders reasonably fail to believe in God.

(3') At least some good responders reasonably fail to believe in God.

(4) No perfectly loving God exists. [from 2, 3]

(5) There is no God. [from 1, 4]

There is also a distinct worry for those who would reject (3') and claim that all of those who reasonably fail to believe are, in fact, bad responders. This worry is that God could turn a bad responder into a good responder by placing him in different circumstances (circumstances more favourable to a good response) without thereby manipulating him. For example, a morally corrupt person could have been informed of God's existence before she had a chance to become morally corrupt or placed in such an environment where she would not have been corrupted in the first place. Thus, someone who 
wishes to invoke the improper response objection must also explain why God does not put everyone in situations where they would be likely to be good responders.

One move which some theists have made in order to respond to this worry appeals to a Molinist account of divine providence. Molinism is (at least in part) the view that God has knowledge of counterfactuals of creaturely freedom..$^{15}$ Counterfactuals of creaturely freedom tell God how each possible free person would act in each of the different circumstances in which God could place her. Thus God knows ahead of time whether a particular person would respond well or badly if the person came to believe in God in any particular circumstance. Some theists (Craig 1995, Thune 2006) have suggested that God knows that some people would be bad responders no matter what circumstances they were placed in. Thus he knows that he cannot place them in circumstances in which they would be good responders.

This move provides only a limited benefit to the theist. First, it is not at all obvious that God can have knowledge of such counterfactuals of creaturely freedom. ${ }^{16}$ Second, although perhaps there is some person who would respond badly to belief in God in every possible situation, it seems quite unlikely that there would be many for whom this would be true. Third, this view does nothing to address the main problem with the improper response objection which is that we apparently know that many actual people would respond well if they learned of God's existence. ${ }^{17}$

So it appears that the improper response objection provides us with (at best) a partial solution. We may now have reason to think that some reasonable nonbelief will occur, but we still cannot account for all of the reasonable non-belief that actually occurs. The only way to strengthen the defence to show that all actual non-belief is necessary has false implications and thus fails the second criterion of a successful defence.

\section{Objections to premise (3)}

As noted above, most of the extant criticisms of the argument from divine hiddenness attempt to craft a defence that shows that premise (2) is unsupported, i.e. attempts to show that even if God exists we should not expect that he would eliminate reasonable non-belief. However, a more robust response to the argument accepts this premise but denies premise (3), to wit, denies that there are any reasonable non-believers (e.g. Lehe (2004), Moser (2001), (2004)). In places, this seems to be the response to divine hiddenness favoured by Blaise Pascal: “" But', " you say, "if he [God] wanted me to adore him, he would have left some signs of his will.” And so he has, but you have ignored them' (Pascal (1995), 58). This section canvasses both of the prominent responses of this sort and shows 
that each fails for the same reason as the defences offered above fail: they are implausible given our other commitments.

\section{Sin}

There is a long history - at least within the Western tradition - of blaming cognitive failure on moral failure. According to this tradition, sin has noetic effects. Hence one way of objecting to premise (3) is to show that non-belief in God is the result of $\sin$ and thus those who are non-believers are at fault in some way for their unbelief. This sort of response can be traced at least as far back as Calvin in the Western tradition and has been endorsed in one form or another by a number of contemporary philosophers (Talbot (1989); Morris (1992), 96; Schellenberg (1993), 74-82; Murray (1993), 35; Plantinga (2000); Henry (2008), 279). As an example of this move, consider Plantinga (2000):

\footnotetext{
The most serious noetic effects of sin have to do with our knowledge of God. Were it not for sin and its effects, God's presence and glory would be as obvious and uncontroversial to us all as the presence of other minds, physical objects, and the past. Like any cognitive process, however, the sensus divinitatis can malfunction; as a result of sin, it has indeed been damaged. (214)
}

In order to evaluate this particular response, we should note that some forms of the argument from divine hiddenness take reasonable or rational non-belief to be theistically problematic and others take non-culpable non-belief as the relevant notion. The sin response can be dismissed on either reading of the argument.

Assume first that the argument from divine hiddenness requires that there be rational non-belief. Here is the sense of rationality that Schellenberg (1993) has in mind:

$\mathrm{S}$ has a rational belief that $p$ if and only if his evidence, inductive standards, and belief as to $p$ 's probability on the evidence have been, in his own view at the time, adequately investigated. (61)

The idea is that an epistemic state is rational for you just in case you have investigated the issue by your own lights and come to believe that your investigation is adequate to support the epistemic state of believing, withholding belief, etc. This is an egocentric view of rationality of the sort defended by Foley (1993) and others, and many agree that it's roughly the right account. Given this account, would the existence of sin show how non-belief in God is not rational?

No. Suppose it were true that one's sin obscures evidence, impacts one's ability to 'see' the logical entailments of one's beliefs, makes accurate probability assignments difficult, etc. Given these impediments, it's quite plausible to think that there could still be a person who - in her own view of things at the 
time - would come to think that her evidence and inductive standards fail to support the belief that God exists. The basic problem for the sin objection is this: having damaged cognitive faculties or reduced evidence makes it even easier to have rational non-belief! For example, it is not rational for us to fail to believe that sugar causes cavities. It is, however, rational for someone who lacks the appropriate evidence to fail to believe this. Similarly, it is rational for someone who has the appropriate evidence but who is literally unable to 'see' the connection between sugar and cavities to fail to believe this. Rationality is person-relative, and as long as a person adequately investigates his evidence and finds that the evidence doesn't seem to support a belief, it is rational for him to be a nonbeliever. And so weakening the investigative tools of the mind only makes the set of things that are not rational to believe larger.

Assume next that the argument from divine hiddenness requires that there be non-culpable non-belief. How could sin show that non-belief was culpable? The $\sin$ at issue is either one's own or someone else's. If one's non-belief is the result of what someone else did, then one is not culpable for the non-belief. After all, we're not responsible for what other people do. If Justin's cognitive state is a result of Philip's sin, it is not true that Justin is culpable for being in that cognitive state. So, if it is true that sin can account for the culpability of one's non-belief, it must be one's own sin that is at issue.

But even in this case it is not true that sin shows that non-belief is culpable. Consider the following necessary condition on responsibility or culpability for the consequence of an action:

A subject $S$ is culpable for a consequence $C$ of an action $A$ only if $S$ believed (or should have believed) that there was a not insignificant chance that $A$ would result in $C^{18}$

The gist is that one is responsible only for consequences of an action that were foreseen (or were reasonably foreseeable). For example, suppose that unbeknownst to Philip, terrorists rig his light switch to detonate a bomb under a local building. When Philip enters the room and flips the switch, this action has the consequence that a building is destroyed by the bomb. Is Philip responsible for this consequence? No - he did not know that his action of flipping the switch was at all likely have this result, nor should he have known this. So he is not culpable for the result.

Now consider the matter of sin. Is it true that non-believers knew (or should have known) that sinning would have noetic consequences? No. There is no apparent connection between committing an action that is morally wrong (assuming that is what it means to sin) and damaging one's evidence, mental abilities, etc. In fact, a great many philosophers deny that this is true. It is not clear that doing something that is morally wrong has a unique effect on one's epistemic situation. ${ }^{19}$ And if, like Calvin, the objector insists that the epistemic effects are the result of sins committed early in one's life, our criticism is even 
more potent: no children are in a position to know whether or not their sins will affect their future ability to gather evidence about the existence of God, etc. In general, it appears that those who wish to claim that all non-belief is culpable must make implausible claims about the conditions under which one is culpable for the consequences of one's behaviour. Our conclusion is that there is no good criticism here of premise (3).

\section{G. E. Moore shift}

A more radical attempt to deny premise (3) turns the argument on its head by accepting premise (2) as it stands but pairing it with a denial of the conclusion. This pair of claims would then entail the denial of premise (3). Here's how such a case might go. Suppose one is a theist and comes to believe that premise (2) is true, i.e. comes to believe that if a perfectly loving God exists, there would not be any reasonable non-belief. It follows trivially that given one's belief that a perfectly loving God exists, all of the examples of apparently reasonable non-belief that one has encountered are illusory. Premise (3) is false after all. This kind of G. E. Moore shift is implausible when applied to the argument from evil because it is so obvious that evil exists. But questions of what it is reasonable for people to believe or whether or not people are culpable for their cognitive states are matters that are certainly much less obvious.

However, this response faces an explanatory burden: if it's true that belief in God is actually reasonable for everyone (i.e. premise (3) is false), what accounts for the fact that there are so many apparently reasonable non-believers? Well, the theist might resort to a response favoured by Schellenberg himself in a quite different context: self-deception. Schellenberg (1993) responds to the objection that belief in God would undermine moral freedom by insisting that 'moral commitment need not follow upon the formation of theistic belief because such belief can be successfully resisted' (110). Thus Schellenberg imagines a class of people for whom the belief in God is reasonable but - as a result of selfdeception - this belief does not 'stick' (i.e. it does not impact their other mental states or their behaviour). The same strategy is open to the objector who denies that there are any reasonable non-believers as a result of the G. E. Moore shift: the class of apparently reasonable non-believers is actually made up of nonreasonable non-believers who appear reasonable as the result of self-deception. ${ }^{20}$ They have been presented with evidence sufficient for belief in God, but the belief does not 'stick'. Consider Schellenberg (1993):

Where motives for self-deception exist (and they seem not to be lacking in the religious case), an initial inclination to believe can be overcome, for example, through looking at the evidence for and against again but selectively, and then taking steps to forget having done so. This is all the more possible where ... the evidence does not render the proposition in question certain; any small margin of 
negative probability can be blown all out of proportion if one has the requisite motives. (110)

Other authors have exploited the possibility of self-deception as a way of undermining premise (3), ${ }^{21}$ but combining the possibility of self-deception with the G. E. Moore shift actually provides a case for denying premise (3).

Whether or not this response is ultimately successful depends on the strength of a particular individual's beliefs. The problem is one of reconciling an inconsistent set:

(A) A perfectly loving God exists.

(B) If a perfectly loving God exists, then there is no reasonable non-belief.

(C) There is reasonable non-belief.

For one who finds (A) and (B) individually more plausible than (C) - especially given self-deception - the G. E. Moore shift described above provides a reasonable response to the argument for divine hiddenness. But since this response ultimately depends on the subjective probabilities of each person, it would be valuable if there were a more straightforward response to the argument. (Such a response is suggested in the next section.) Furthermore, given that $(\mathrm{C})$ does have significant initial plausibility, even those who find (A) and (B) individually more plausible than (C) should still lower their credence in (A) and (B) if the only reason they have for rejecting (C) is the conflict with (A) and (B). Thus the G. E. Moore shift is at best a response to the argument from divine hiddenness whose success depends on a successful case for the existence of God.

\section{Going forward: the sceptical response}

Where do we go from here? As we see it, the theist must opt for one of three possible responses to the argument from divine hiddenness:
Theodicy:
(i) develop an account of why God would create a world in which reasonable non-belief occurs and (ii) provide reasons for thinking that this account is true.
Defence:
(i) develop an account of why God would create a world in which reasonable non-belief occurs and (ii) show that this description is true for all we know (i.e. at a minimum show that this account is compatible with other things that we know or confidently believe).
Scepticism: develop a reason for withholding belief about whether or not God would create a world in which reasonable non-belief occurs.

The theodicy route would show that the major premise of the argument from divine hiddenness is false. The defence or scepticism route would show that we're not justified in believing the major premise of the argument from 
divine hiddenness. Thus any of these routes would successfully challenge the argument.

We have shown here that major contemporary defences fail the second condition of a successful defence. And if these accounts fail as defences, a fortiori they fail as theodicies. We close this article with a brief discussion about the prospects of the third alternative, scepticism. Such scepticism is often called 'sceptical theism' in the philosophy of religion literature. ${ }^{22}$ We argue here that a position in this neighbourhood is a more promising response to the argument from divine hiddenness than either of the other options, i.e. we think that no-one is in a position to determine whether or not the argument from divine hiddenness is sound. And on the face of it, anyone who carefully considers our epistemic position vis-à-vis God should be agnostic about whether or not he would ensure that all people at all times have full belief in his existence. We think this reasonable position can be found, among other places, in the thought of David Hume:

\footnotetext{
The great source of our mistake in the subject of God, and of the unbounded 'license to suppose' that we allow ourselves, is that we silently think of ourselves as in the place of the supreme being, and conclude that he will always behave in the way that we would find reasonable and acceptable if we were in his situation. ${ }^{23}$
}

In the rest of this article, we will differentiate the sceptical response we prefer from either the theodicy or the defence strategy, illustrate the reliance on this strategy by some of those pressing the argument from divine hiddenness, discuss how the sceptical strategy bears on two variants of the argument from divine hiddenness, and respond to four objections to such scepticism.

First, notice that the sceptical response to the argument from divine hiddenness is importantly different from the theodicy or defence strategy. The theodicy attempts to tell us what the compensating good actually is. The defence attempts to tell us what the compensating good might be. The former fails because it assumes too much of our knowledge of God, and the latter fails because it is plausible that each of the goods mentioned in the defences can be achieved without non-belief. The strategies are united in that each of them makes claims about why God is or might be required to hide evidence of his existence given some compensating good, etc. and leverages this modal/theological claim to cast doubt on the relevant premise of the hiddenness argument.

However, it is possible to be sceptical about the argument from divine hiddenness without making such assumptions. We need not offer a suggestion about what God's reasons are (might be) in order to defend a limited scepticism about our expectations of divine behaviour. Instead of providing a full-blown argument for this conclusion (for which there is simply not room), note that Schellenberg the primary defender of the hiddenness argument - employs this same strategy when it is convenient for his purposes to do so. For example, his argument 
requires that if God exists, he would ensure that all non-culpable agents would have a weak belief in the existence of God. He considers the following objection: why not think that if a perfectly loving God exists he would ensure that all people had a strong belief in his existence rather than merely a weak belief? Surely a strong belief in the existence of a person is a better foundation for a relationship with her than a weak belief in her existence. And so God would ensure strong belief in his existence.

Schellenberg's (1993) response to this objection is instructive: 'God might have reasons for leaving me for a time in a state of weak belief and, given that firm belief is not required for a personal relationship with God [he need not ensure it]' (33). This is the sceptical strategy par excellence. Despite the fact that strong belief in the existence of God is a good thing, Schellenberg allows that God may have good reasons for not ensuring that that good thing obtain (even though he offers no suggestion as to what this other good either is or what it might be). The sceptical response to the argument from divine hiddenness is parallel: despite the fact that weak belief in the existence of God is a good thing, God may have good reasons for not ensuring that that good thing obtain (even though we can offer no suggestion as to what this other good might be).

Third, note that this sort of sceptical response applies to variations of the argument from divine hiddenness as well as to Schellenberg's original formulation. Recall the reformulation of the argument we suggested in response to the improper-response defence above. Our reformulation appealed to the following premise:

(2') If a perfectly loving God exists, no good responders reasonably fail to believe in God.

The sceptical response gives us the resources to call (2') into question. Granting that it would be good for good responders to believe, it is still the case that, for all we know, God has good reasons for not ensuring that no good responders reasonably fail to believe (reasons of which we are unaware).

Schellenberg (2007) has recently introduced his own more sophisticated version of the argument from hiddenness. His new version makes use of the following claim:

Necessarily, if God exists, anyone who is (i) not resisting God and (ii) capable of meaningful conscious relationship with God is also (iii) in a position to participate in such relationship (able to do so just by trying). (204)

This claim can be called into question for the same sorts of reasons delineated above. It is true that it would be good for those who meet conditions (i) and (ii) to be in a position to participate in a relationship with God. However, it may still be the case that God has good reasons not to place some of those who meet conditions (i) and (ii) in such a position. And given our epistemic situation vis-à-vis 
God, it is reasonable to withhold judgement on this condition even though we are in no position to suggest what the possible good is or might be.

Finally, this sort of scepticism about arguments for atheism has been roundly abused in the contemporary literature. We close by dealing with four of the most common objections. First is this: the sceptical theist tells us that it's not reasonable to believe that a perfectly loving God would ensure that it's reasonable for all people to believe in him. But if one is sceptical about this, then one must be sceptical about all other sorts of interpersonal claims. Thus the strategy outlined here is not open to anyone who doesn't otherwise want to be a sceptic about our relationships with other people.

This objection is too fast. Consider again David Hume on this issue:

In human nature, there is a certain experienced coherence of designs and inclinations; so that when from some fact we discover one intention of a man, it may often be reasonable in the light of experience to infer another, and draw a long chain of conclusions about his past or future conduct. But this method of reasoning can never have place with regard to a being who is so remote and incomprehensible..${ }^{24}$

On the one hand, we have good inductive evidence about how other humans may respond, prioritize, etc. And we have a pretty good idea of the cognitive, moral, and other limitations of fellow humans. So a sceptical theist need not be a sceptic about, say, whether a parent will buy her child a gift at Christmas. But such inductive evidence gives us little reason for drawing conclusions about God, for all sides of the debate can agree that if there is a God, he knows of many more goods, many more strategies for obtaining goods, and many more contingent facts than your average human.

What a sceptical theist is committed to, though, is a general scepticism about our knowledge of what God would do in any particular situation. We don't think that atheists or theists can say with any serious degree of confidence why God does what he does or why he would or wouldn't do a certain thing. But such a scepticism is healthy and not a reason to abandon the position. Two quick examples will suffice, one from an atheist and one from a theist. William Rowe seems to think that if God exists, it is obvious that humans experience a life after death (Rowe (2007), 158), and Alvin Plantinga assumes that if God exists it is obvious that our belief-forming faculties are reliable (Plantinga (2000) ). Given our scepticism, we are not sanguine about either inference (God might well have other interests, motives, etc. than the few that we are able to decipher). And this seems entirely appropriate.

Second, one might worry that if sceptical theism is true we would have no reason to prevent evil (Russell (1996), 197-198). One might think that if we accepted sceptical theism we should believe that the only bad events that God allows to occur are events which are necessary for achieving some good 
sufficient to justify allowing the evil to occur. So when deliberating about whether to prevent an evil one should conclude that either God will prevent it, or else there is a good reason to refrain from preventing it.

A more particular version of this worry can be raised concerning sceptical theism when presented as a response to divine hiddenness. One could argue that those who endorse sceptical theism as a solution to divine hiddenness have no reason to inform people of God's existence. In any situation where there is not a sufficiently strong reason to allow the person to remain ignorant, God himself will do the informing. Thus, either the person will be informed, or there is a good reason not to inform him.

By way of reply, note again that the sceptical theist need not (and probably should not) claim that we are certain that the only evils that occur are ones for which there is a sufficient reason for allowing them to occur. The sceptical theist might instead accept the weaker claim that we do not know that there are evils that occur for which there is not a sufficient reason for allowing them to occur. ${ }^{25}$ And this weaker claim is not enough to make sceptical theism susceptible to the foregoing objection. Even if a sceptical theist were quite confident that God exists and that God's existence is inconsistent with the existence of gratuitous evil, so long as she did not assign a probability of 1 to both of these claims, she might still have a reason to prevent the evil from occurring. This sort of reasoning 'from ignorance' is quite common. You see a dog wandering your neighbourhood. You aren't sure if he knows where he is going or is lost. You don't know for sure whether he will be hit by a car or not. So you catch him and call the number on his collar. Similarly, the sceptical theist who is deliberating about whether to prevent a particular evil could reason as follows:

I am not certain whether or not there is a sufficient reason to allow this evil to occur. But, since I am not sure, it is an open possibility that I will prevent an unjustified evil from occurring. So I have a reason to prevent the evil.

Someone who accepts sceptical theism as a solution to the problem of divine hiddenness could deliberate in a similar manner:

I am not certain whether or not there is a sufficient reason to allow this person to be ignorant of God's existence. But, since I am not sure, it is an open possibility that I will prevent an unjustified evil from occurring. So I have a reason to inform her.

So it appears that sceptical theists need not hold that we never have reasons to prevent evils from occurring.

A third worry for sceptical theism more generally has recently been offered by Dougherty (2008). Dougherty suggests that anyone attracted to sceptical theism cannot endorse any variety of common-sense epistemology, where a commonsense epistemology is roughly one that allows that epistemic properties like justification, knowledge, etc. are relatively easy to come by. Such epistemologies 
can be found in the works of G. E. Moore and Chisholm and have been ably defended by contemporary philosophers such as Michael Huemer, Jim Pryor, and Richard Swinburne. The gist of common-sense epistemology is that the fact that it appears to an agent to be $P$ provides some kind of prima facie justification for that agent to believe that $P$. The putative tension with sceptical theism is then evident: since it appears to many people that God would do a certain sort of thing - given common-sense epistemology - such people are justified in believing that God would do a certain sort of thing. Thus, as long as it appears to the defender of the argument from hiddenness that God would eliminate reasonable non-belief, premise (2) is justified for the defender of the argument from hiddenness. Furthermore, we have relied on such 'common-sense' claims in our rejection of contemporary defences of divine hiddenness. ${ }^{26}$ So aren't we trying to have our cake and eat it, too?

However, even granting that so-called common-sense epistemology is largely correct, there is no tension between such epistemology and the sceptical response. While it might be true that justification is easy to get, everyone grants that even on the most common-sense epistemology, it can be easily lost. And once we reflect on the differences between God and ourselves, this provides a defeater for whatever prima facie justification our beliefs about what God would do initially had. Consider Henry (2008):

We must allow, then, that accounts of divine love are subject to the limits and frailties of our own view from below. Honestly appraising the humble position we occupy reminds us that divine love could be different from what we imagine. (281)

So no doubt, given common-sense epistemology, premise (2) is justified for many people. But once these people are made aware of the case presented above, they have a defeater for premise (2). The conclusion is this: theists need not fear the argument from divine hiddenness because a persuasive case can be made that none of us is all-things-considered justified in accepting premise (2). And this is compatible with accepting common-sense epistemology in broad form.

Fourth, and finally, Erik Wielenberg (2010) has argued that sceptical theism rules out the rational acceptance of divine revelation. Sceptical theists maintain that we are not in an epistemic position to know whether a given evil has a compensating good or whether or not God would have good reasons to remain hidden from us:

skeptical theists are similarly committed to the claim that the fact that we cannot think of a justification for God lying to us does not imply that no such justification exists. This, I argue, leaves us with no good basis for ruling out the possibility of divine lies. And this in turn implies that skeptical theism is at odds with any religious tradition according to which there are certain claims that we can know to be true solely in virtue of the fact that God has told us that they are true. (509) 
Since virtually every mainstream religion relies in some way or other on divine revelation, it is a serious criticism of sceptical theism that it is inconsistent with the acceptance of such revelation.

However, the objection is not as scary as it first appears. True, a sceptical theist should grant the possibility of divine lies. Other things being equal, God would, of course, tell us only what was true. This isn't an all-things-considered judgment but a ceteris paribus one. Only the former is off limits according to sceptical theism. But since we're in no position to determine whether or not the ceteris paribus clause is met, we should allow that it is possible that God is lying to us.

But so what? Does this imply that we should never believe what we think God is telling us or that it is epistemically inappropriate to trust a source when we know that it's possible that the source is deceptive? Not if we allow that in at least some cases we should believe what other people are telling us. If so, then we are committed to the view that it is epistemically appropriate to trust a source even when we know that it's possible that the source is deceptive. People have deceived us in the past. And in many cases, we simply can't tell whether they are being deceitful in any given instance. And yet we think it's perfectly rational to accept the testimony of such people. Thus it is appropriate to accept testimony in general even though we know it is possible that the testimony is misleading. Given this epistemic fact, it is also appropriate to accept the testimony of God even though we know that it is possible that God is deceiving us.

In conclusion, the contemporary responses to the argument from divine hiddenness share the same defect as the argument itself: they each assume that we can know too much. Sceptical theism, on the other hand, shows not only why such responses fail but why the argument itself fails. And the objections to sceptical theism are either straw men or easily defused. ${ }^{27}$

\section{References}

Craig, William (1995) 'Politically incorrect salvation', in T. P. Phillips and D. Ockholm (eds) Christian Apologetics in the Post-modern World (Downer's Grove IL: Inter-Varsity Press), 75-97.

Drange, Theodore M. (1998) 'Nonbelief vs. lack of evidence: two atheistic arguments', Philo, 1, 105-114. Flint, Thomas (1998) Divine Providence: The Molinist Account (Ithaca: Cornell University Press).

FOLEY, RICHARD (1993) Working without a Net: A Study of Egocentric Epistemology (Oxford: Oxford University Press).

Hasker, William (1998) God, Time, and Knowledge (Ithaca: Cornell University Press).

Henry, Douglas V. (2008) 'Reasonable doubts about reasonable nonbelief', Faith and Philosophy, 25, 276-289.

HICK, JoHn (1971) Arguments for the Existence of God (London: Macmillan).

HoWARD-SNYDER, DANIEL (1996) 'The argument from divine hiddenness', Canadian Journal of Philosophy, 26, 433-453.

Hick, JoHN (2002) 'Introduction: the hiddenness of God', in Daniel Howard-Snyder and Paul K. Moser (eds) Divine Hiddenness: New Essays (Cambridge: Cambridge University Press), 1-23.

Hume, DAVID (2007) Enquiry Concerning Human Understanding, Peter Millican (ed.) (Oxford: Oxford University Press). 
Keller, JAMES A. (1995) 'The hiddenness of God and the problem of evil', International Journal for Philosophy of Religion, 37, 13-24.

LEHE, ROBERT T. (2004) 'A response to the argument from the reasonableness of non-belief', Faith and Philosophy, 21, 159-174.

MAItZen, Stephen (2006) 'Divine hiddenness and the demographics of theism', Religious Studies, 42, 177-191. McBrayer, Justin (2006) 'On “A Molinist-style response to Schellenberg” by Michael Thune', Southwest Philosophy Review, 22, 71-76.

(2010) 'Skeptical theism', Philosophy Compass, 5, 611-623.

MCKiм, Roвert (1990) 'The hiddenness of God', Religious Studies, 26, 141-161. (2001) Religious Ambiguity and Religious Diversity (Oxford: Oxford University Press).

Morris, Thomas V. (1992) 'The hidden God', in Making Sense of it All (Grand Rapids MI: Eerdmans), 85-108. Moser, PAul K. (2001) 'A god who hides and seeks', Philosophia Christi, 2, 467-473.

(2004) 'Does divine hiddenness justify atheism? Divine hiddenness does not justify atheism', in Michael

Peterson (ed.) Contemporary Debates in Philosophy of Religion (Malden MA: Blackwell Publishing), 42-54.

Murray, Michael (1993) 'Coercion and the hiddenness of God', American Philosophical Quarterly, 3o, 27-38. (2002): 'Deus absconditus', in Daniel Howard-Snyder and Paul K. Moser (eds) Divine Hiddenness: New

Essays (Cambridge: Cambridge University Press), 62-82.

Pascal, Blaise (1995) Pensées and Other Writings, trans. Honor Levi (Oxford: Oxford University Press).

Plantinga, Alvin (2000) Warranted Christian Belief (Oxford: Oxford University Press).

RosEN, GIDEON (2008) 'Kleinbart the oblivious and other tales of ignorance and responsibility', Journal of

Philosophy, 105, 591-610.

SCHELlenberg, J. L. (1993) Divine Hiddenness and Human Reason (Ithaca NY: Cornell University Press). (1996) 'Response to Howard-Snyder', Canadian Journal of Philosophy, 26, 455-462.

(2005a) 'The hiddenness argument revisited (I)', Religious Studies, 41, 287-303.

(2005b) 'The hiddenness argument revisited (II) ', Religious Studies, 41, 287-303.

(2007) The Wisdom to Doubt (Ithaca NY: Cornell University Press).

Swinburne, Richard (2004) The Existence of God (Oxford: Oxford University Press).

TALBOT, MARK R. (1989) 'Is it natural to believe in God?', Faith and Philosophy, 6, 155-171.

Thune, Michael (2006) 'A Molinist-style response to Schellenberg', Southwest Philosophy Review, 22, 33-41.

Van Inwagen, Peter (2006) 'The Hiddenness of God', in The Problem of Evil (Oxford: Oxford University

Press), 135-151.

WielENBERG, ERIK (2010) 'Skeptical theism and divine lies', Religious Studies, 46, 509-523.

\section{Notes}

1. Other defenders of this basic line of thought include an informal argument by Bertrand Russell and a formal version presented by Drange (1998).

2. Schellenberg (1993), 83.

3. See Schellenberg (2007), 204-206 for the stronger version of the argument.

4. Schellenberg (2007) presents a modally stronger version of the argument.

5. Murray presents his account as a partial response which is supposed to explain why God fails to 'provide a grand, universal display of general revelation'. Many of our criticisms will apply even if the scope of Murray's response is taken to be limited in this way. However, we will proceed as though his response were offered as a full-blown solution to the problem of hiddenness because we are primarily interested in whether any such solutions exist.

6. If choices made in such a state would even be free at all.

7. In fact, we deny that there are genuine reasons to fear God, so we don't think that there are facts that could be joined with the belief in God that would result in coercion. But that is a substantive issue that we cannot tackle here.

8. One might maintain that option (a) is not that unattractive. One could hold that most theists have moments when they are not confident enough about the existence of God to know that God exists, and that all of their morally significant free choices occur during these moments. But even this response forces us to deny something that seems perfectly obvious: often people make morally significant free choices (both good and bad) while being extremely confident that God exists, e.g. the September 11 bombers.

\section{CAMBRIDGE JDURNALS}


9. Another response which could be made here would be to claim that some people gain knowledge of God's existence only after voluntarily entering into a certain covenant with God. And that those who are in this covenant are exempt from the threat provided by God's existence. Thus, they need not be coerced and can still make morally significant free choices. The problem with this response is that it seems that one must already be aware of God's existence in order to voluntarily enter into a covenant with him.

10. Perhaps the coercion response is an instance of this second genre since one might argue that hiddenness is necessary to preserve the good of moral freedom. We opted to think about a case of coercion as a case of moral wrongdoing, and thus thought of the coercion response differently: hiddenness is necessary to prevent God from acting wrongly. Nothing much hangs on the division. Thanks to Andrew Moon for pointing this out.

11. Swinburne actually suggests that divine hiddenness secures two goods, this being one of them. The other good is the good that religious believers get from being able to 'witness' to the unbelievers. However, it doesn't seem that it would be a good thing to keep one of your children ignorant simply so that another of your children could have the good of teaching him. Similarly, it seems to us that what good this provides is so slight that it's implausible that it 'trumps' the good that the unbelievers would receive from knowing God, though, strictly speaking and following our scepticism as defended in the opening section of this article, we remain agnostic about this value judgement.

12. This objection admittedly does not apply to Pascal's suggestion, but his view faces problems of its own, assuming that being in a relationship with God is a great good for an individual and that most people have the general desire to possess great goods. God would be frustrating some of the preferences of non-believers by remaining hidden. Furthermore, there appear to be people who reasonably refrain from believing in God but wish and/or hope that God exists. They might also want to have a relationship with God. Consider prayers such as 'God, if you're out there, will you let me know?' These people's preferences would apparently be fulfilled rather than frustrated were they to learn of God's existence.

13. Thanks to an anonymous reviewer for Religious Studies for pointing out this objection to the improper response defence.

14. A related point is made by Maitzen (2006) in response to a different objection to the argument from divine hiddenness.

15. For an exposition and defence of Molinism see Flint (1998).

16. See Hasker (1998) for an argument that God cannot have such knowledge.

17. This point is made in McBrayer (2006).

18. We find this principle intuitively very plausible. We do not have room here for an in-depth defence of it, but for a recent defence of a very similar view see Rosen (2008).

19. Perhaps it's true that all actions have some effect on one's epistemic situation. For example, raising your arm might make things seem different to you, alter your memories of what you have done, provide new evidence, etc. What we find dubious is the claim that there is anything special about moral actions - there is nothing about an act of moral wrongdoing that is unique in this respect.

20. Justin McBrayer suggested this move in a presentation at the Divine Hiddenness Conference, University of Colorado Philosophy Department and the Theology Forum, Boulder, Colorado; 21-23 October 2004.

21. See Howard-Snyder (2002), 10, and Henry (2008), 283-286.

22. See McBrayer (2010) for an overview of sceptical theism.

23. Hume (2007), §11.

24. Ibid.

25. Our version of sceptical theism is not even committed to this mild claim. Our view is merely that we should not expect to be able to predict how God will behave all-things-considered. It is consistent with our view to hold that a morally perfect being could allow gratuitous evils to occur (similar to the claim made by Van Inwagen 2006).

26. Thanks to an anonymous reviewer for Religious Studies for pointing this out.

27. The audience at the 8th Annual Intermountain West Graduate Philosophy Conference, at the University of Utah, Salt Lake City, Utah in April 2011 provided very helpful feedback on a draft of this article. Similarly, Kenny Boyce, Mat Konieczka, Andrew Moon, Dugald Owen, and Patrick Todd as well as an anonymous reviewer for Religious Studies all provided substantive and careful feedback on written versions of this article. We are grateful for their penetrating insight and clear, thoughtful commentary. 